Aiste Celkyte*

\title{
The Soul and Personal Identity in Early Stoicism: Two Theories?
}

\author{
https://doi.org/10.1515/apeiron-2017-0038
}

Abstract: This paper is dedicated to exploring the alleged difference between Cleanthes' and Chrysippus' accounts of the post-mortal survival of the souls and the conceptions of personal identity that these accounts underpin. I argue that while Cleanthes conceptualised the personal identity as grounded in the rational soul, Chrysippus conceptualised it as the being an embodied rational soul. I also suggest that this difference between the two early Stoics might have been due to his metaphysical commitments arising from his response to the Growing Argument put forth by the Academics rather than the critique of his teacher.

Keywords: stoicism, soul, identity, immortality

One of the fundamental claims of Stoic metaphysics is the corporeality of everything that exists in this world, including the rational soul of human beings. The principles of Stoic materialism are quite complex, however. ${ }^{1}$ The peculiarity of the Stoic position becomes especially clear in the case of their views regarding the post-mortal survival of the soul. At the beginning of the Tusculan Disputations, there is the following classification of philosophical accounts concerning this issue: (i) death is the perishing of both body and soul; (ii) death is the separation of the body and the soul. The latter can be further divided into the following subcategories: (ii. a) the soul dissolves immediately after the separation; (ii. b) the soul continues to exist for some time; (ii. c) the soul exists for eternity. ${ }^{2}$ The Stoic account belongs to the category (ii. b). ${ }^{3}$ This view is noted for its oddity. The Stoics are said to admit the difficult point that the human soul has an independent existence from the body, only to reject the

1 For a study of Stoic materialism and its implications, see Vogt (2009). Cf. Gourinat (2009) for an argument that very notion of materialism might not be very useful when trying to understand the Stoic stance because Stoic philosophy has traits of both materialism and dualism.

2 Cic. Tusc. 1.9.

3 Epictetus might have been an exception; see $D$ 3.13.14-15.

*Corresponding author: Aiste Celkyte, Philosophy and Religious Studies, Janskerkhof 13, 3512 BL Utrecht, Netherlands, E-mail: aiste.celkyte@gmail.com 
very simple claim - which also seems to be a natural consequence of their first point - that the soul most likely exists for eternity. ${ }^{4}$

The claim that souls survive death but last only for a certain period of time is highly unusual. The number of supporting fragments is not very high but substantial enough to show that the view must have been a well-known part of the Stoic doctrine. There are two kinds of questions that can be asked about this material. The first and most obvious one concerns the Stoic account of the postmortal survival of the soul. Why does the soul survive at all? Why does it survive only for a little bit as opposed to for eternity? The post-mortal survival of the soul is not necessarily impossible in a materialist framework; after all, if the soul is material, its matter obviously does not simply disappear once it is dead. Yet, true materialists are typically committed to the view that identity does end with death, even if the substratum continues to exist. What is especially interesting in the Stoic case, therefore, is the question of whether the claim that souls survive post mortem means that 'we' survive our death. What kind of a view on personal identity does, then, the Stoic account of the post-mortal existence of the soul imply? This is the second kind of question concerning this material that ought to be raised. In a sense, the issue at stake is the persistence of identity because the fundamental question here is whether death is the kind of change through which identity is capable of persisting.

\section{Sources: Chrysippus vs. Cleanthes}

The evidence for settling these questions is, as it is so often the case with early Stoic material, not only fragmentary but also problematic. Most texts ascribe the account of the post-mortal survival of the soul as described in Tusculan Disputations to 'the Stoics' in general. Diogenes Laertius, however, claims that there were, in fact, two fairly different views as follows:

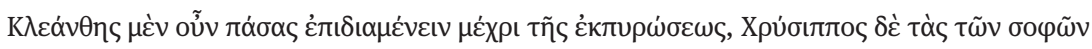
uóvov.

Cleanthes indeed holds that all souls continue to exist until the general conflagration; but Chrysippus says that only the souls of the wise do so. ${ }^{5}$

According Diogenes Laertius, then, there is a fairly significant difference between the views held by Cleanthes and Chrysippus. The former allowed that

4 Cic. Tusc. 1.32.

5 Diog. Laert. $7.157=$ SVF 2.811, tr. Hicks. 
all souls survive until the end of the world cycle, while Chrysippus claimed that only the souls of the wise survive for such a long time. ${ }^{6}$ For the sake of precision, the first issue that ought to be clarified here is what it means to cease to exist in this context. The matter out of which both bodies and souls are made does not, of course, cease to exist. Ceasing to exist must be the transformation of a soul in such a way that it cannot be identified as a 'soul' anymore. The conflagration is the point at which all qualified individuals cease to exist. ${ }^{7}$ It is possible that Cleanthes claimed that the conflagration is the cut-off point for the existence of souls for this reason. The view attributed to Chrysippus, meanwhile, is more idiosyncratic. He suggests that the majority of souls disintegrate much earlier, although, in exceptional cases, some souls last until the end of the world cycle. ${ }^{8}$ It is notable that no other source mentions such a disagreement and generally the extant fragments attribute a single view to 'the Stoics.' Are there reasonable grounds for trusting Diogenes Laertius' report that there was a disagreement between Cleanthes and Chrysippus regarding the post-mortal survival of the soul? ${ }^{9}$

I would argue that Diogenes Laertius' testimonial ought not to be dismissed without consideration, because the extant suggests that Chrysippus and Cleanthes had disagreed on a number of issues, some of them concerning the nature and the activities of the soul. Seneca, for instance, argues that it is not always necessary to follow Stoic orthodoxy because even the early Stoics disagreed. According to him, Cleanthes and Chrysippus did not agree on what walking was, because 'Cleanthes said it was breath extending from the commanding-faculty to the feet, Chrysippus that it was the commanding faculty itself. ${ }^{, 10}$ In Diogenes Laertius, moreover, Cleanthes is said to maintain that virtue cannot be lost once it is acquired, while Chrysippus argued that virtue can be lost in the case of intoxication or depression. ${ }^{11}$ Calcidius records the disagreement regarding the theorisation of fate

6 See Hoven $(1971,47)$ for the argument that Chrysippus' claim ought to be interpreted with reference to the conflagration here as well.

7 See Alexander of Aphrodisias in An. Pr. 180,33-36, 181,25-31; Cooper (2009, 104). Interestingly, Cleanthes and Chrysippus have slightly different accounts of conflagration, see Salles (2009) for an in-depth discussion.

8 The wise men are, after all, extremely rare. Alexander of Aphrodisias (Fat. 199.14-22=SVF $3.658=$ LS $61 \mathrm{~N}$ ) claimed that the Stoic wise man is rarer than a phoenix.

9 This apparent disagreement is fairly rarely discussed in the scholarship on this topic. A. E. Ju mentions the disagreement between Cleanthes and Chrysippus $(2009,115)$, but it does not play an important role in her interpretation.

10 Seneca Ep. 113.23=SVF 2.836=LS 53L, tr. Long and Sedley (Cleanthes ait spiritum esse a principali usque in pedes permissum, Chrysippus ipsum principale). See Inwood (2014, 69-74). 11 Diog. Laert. 7.127= LS 611. 
and providence as follows: according to Chrysippus, everything in accordance with fate is also due to providence and vice versa; according to Cleanthes, not all things that come about by fate are products of providence. ${ }^{12}$ Cleanthes and Chrysippus also seem to have held different views regarding the nature of impressions (the former called them imprints, the latter claimed that they were alterations in the soul) ${ }^{13}$ as well as the question of whether all the virtues refer back to the same state of mind (as Cleanthes states) or are separate branches of knowledge (as Chrysippus argues). ${ }^{14}$

The nature of the disagreements between Cleanthes and Chrysippus has been discussed in the scholarship as well. Malcolm Schofield, for example, shows that, in the case of the Stoic theory of cardinal virtues: 'Chrysippus seems to have agreed with Cleanthes about the structure appropriate for a theory of cardinal virtues, while radically disagreeing with him about the substantive content of the theory. ${ }^{15}$ It has also been suggested by David Sedley that the source of the disagreement between Cleanthes and Chrysippus, apart from the general issue of which account would be the best philosophically, was the best interpretation of Zeno's position. ${ }^{16}$

There is, therefore, a sufficiently good reason not to dismiss Diogenes Laertius' claim that Cleanthes and Chrysippus had different views regarding the post-mortal survival of the soul and to investigate how substantial this difference is. In addition to this, it is necessary to ask whether this seemingly slight difference in the early Stoics' account of the soul led to different conceptualisations of personal identity and the scope of its persistence.

\section{Sources: Eusebius, Ps. Plutarch and Others}

There are quite a few extant fragments on the Stoic views of the post-mortal survival of the soul but possibly the most explicit and lengthiest record is found in Eusebius. ${ }^{17}$ In Book 15 of his Preparation for the Gospel, Eusebius describes

12 Calcidius $144=$ SVF 2.933=LS 54U. See Bobzien (1998, 46-47).

13 Sextus Empiricus $M$ 7. 227-241.

14 Plut. Mor. 441A-C and 1034C-E. Schofield (2013) is very useful for untangling the argument here. Cf. Gourinat (2007, 217-241).

15 Schofield (2013, 22).

16 Sedley (2003, 15-16). On the difference between Zeno and the rest of the early Stoics regarding ethics, see Rist (1977).

17 The fragments not discussed in this section will be referred to later when they are relevant to the discussion. 
the views held by various Greek philosophers. When he reaches Stoicism, he provides the following account:

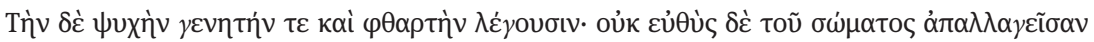

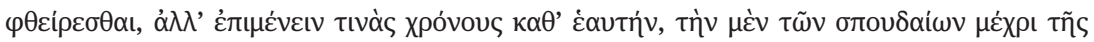

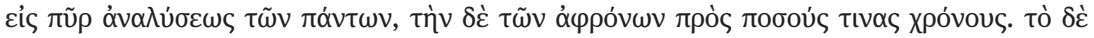

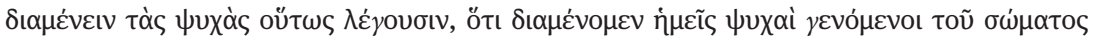

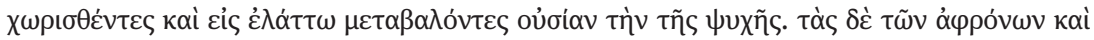

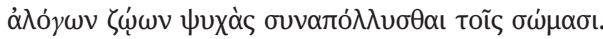

They [the Stoics] say that the soul is subject to generation and destruction. When separated from the body, however, it does not perish at once but survives on its own for certain times, the soul of the virtuous up to the dissolution of everything into fire, that of fools only for certain definite times. By the survival of souls they mean that we ourselves survive having become souls separated from bodies and changed into the lesser substance of the soul, while the souls of non-rational animals perish along with their bodies. ${ }^{18}$

Assuming that Diogenes Laertius' report regarding the disagreement between Cleanthes and Chrysippus is true, Eusebius' passage describes the view held by Chrysippus. Two points indicate this: first, the distinction between ordinary and wise souls and, second, the claim that the latter last until the conflagration, while the former disintegrate sometime after death. A short passage from Pseudo Plutarch records the same view but with some enlightening details. He states the following:

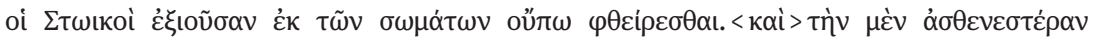

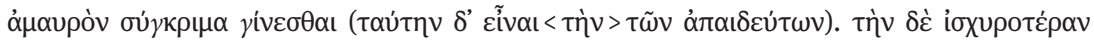

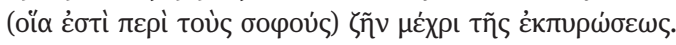

When (the souls) leave the bodies, the Stoics say they do not immediately perish. The weak ones become dark compounds (these are the souls of the ignorant). The strong ones, however, (such as the souls of the wise men) live until the conflagration. ${ }^{19}$

The central claim here is the same as the one found in Eusebius and Diogenes Laertius, that is, wisdom determines how long human souls will survive after death. The wise souls last until the conflagration, while the ordinary ones cease

18 Eusebius Praep. Evang. 15.20.6 = SVF 2.809= LS 53W, tr. Long and Sedley, slightly amended ('having become souls' instead of 'as souls' in the second line from the bottom). Eusebius claims that his source for the views he records in Book 15 is Arius Didymus. See Chiesara (2001, 77) for a suggestion that Arius Didymus' source might have been Posidonius.

19 Ps. Plut. Plac. 4.7, $3=$ SVF 2.810, translation is mine. This passage is not found in Stobaeus, another source for the epitome of Aetius. Despite the fact that there seems to be a certain similarity between this passage and the one preserved by Eusebius, no connection can be established with certainty between Arius Didymus and Aetius, see Mansfeld (2016, 164-168). 
to exist earlier. This short passage, however, also states that ordinary souls disintegrate into other, 'dark', compounds and that the souls of the wise are strong. Strength, I argue below, is of crucial importance when explaining the longevity of the wise souls.

Eusebius and Ps Plutarch are arguably the best sources for the Stoic views on the post-mortal survival of the souls as they are the longest and provide the most details. ${ }^{20}$ Yet, if it is accepted that Diogenes Laertius' report is accurate regarding the difference between Cleanthes' and Chrysippus' views, then the account found in Eusebius and Ps Plutarch is Chrysippean. Before delving into its analysis, however, it is necessary to clarify Cleanthes' theorisation of the human soul and personal identity.

\section{Cleanthes' View: On Being 'Soul Alone.'}

Cleanthes, according to Diogenes Laertius, maintained that all souls survive until conflagration. Arguably, this claim implies that personal identity is grounded in the existence of the soul. Such an interpretation of the Stoic theorisation of the soul and, to some extent, identity is discussed by A.A. Long in his article 'Soul and Body in Stoicism.' The article contains the argument that the Stoics thought of the body and the soul as two distinct substances and, generally, were leaning towards Platonic dualism rather than the view that the psychic existence emerged from the functions of bodily organs. ${ }^{21}$ The postmortal survival of the soul is contingent on the development of souls as distinct independent entities co-existing with bodies. ${ }^{22}$ This account of the relationship

20 For example, Cic. Tusc. $1.77=$ SVF 2.822 (Stoici autem usuram nobis largiuntur tamquam cornicibus: diu mansuros aiunt animos, semper negant) briefly describes the same view. One notable difference is the lack of distinction between the ordinary and the wise souls. This omission could be a matter of a simple truncation. The wise souls are extremely rare, and, consequently, the issue of the post-mortal survival of the souls primarily concerns the ordinary souls. Another source, Lactantius Div. Inst. 7.20 = SVF 2.813, presents a Christian interpretation of this Stoic view, in which many details must have been supplied by Lactantius himself.

21 The reason for this is the Stoic supposition 'that an animal needs a body which is completely equipped with all the organs and functions of a flesh and bones body before its soul can come into existence, as the principle of specifically animal life for that flesh and bones body. The soul cannot be an organ of the flesh and bones body because all bodily organs exist before the soul comes into being' (Long 1982, 43).

22 A part of A.E. Ju's article, 'Stoic and Posidonian Thought on the Immortality of Soul', is dedicated to making sense of the complicated evidence on the early Stoic views of the continuing existence of the soul after death. Like A.A. Long, she argues that the soul is an 
of the body and the soul has some significant consequences for the way in which the Stoics conceptualise personal identity, namely, the idea that personal identity is rooted solely in the rational soul. Long's explanation of this issue is lengthy and multi-faceted, but some of the most pertinent points for the current paper are as follows. The Stoic distinction between pneuma as physis and as psyche not only unburdens the soul from being responsible for growth and nutrition, ${ }^{23}$ but also helps to explain why the Stoics maintain that "no causal necessity links bodily changes and all of the soul's reactions to them ... So, while Stoics would no doubt admit that the soul cannot fail to be aware of an empty stomach, they would deny that that awareness automatically triggers a desire to eat. The hunger sensation and the desire to eat are separate states of the soul. The former is an unavoidable psychic reaction to the body; but the latter depends on the soul and the judgement that the soul makes ... The attitude of emotional indifference to bodily pains and pleasures highlights the supposed independence and value of the soul. It explains the tendency to regard the humanity of a man, his real self, as identical to his hegemonikon. ${ }^{24}$ A short fragment that records Cleanthes' view that humans are 'soul alone' further supports this interpretation. ${ }^{25}$

A.A. Long analyses all the Stoic evidence together, but if Diogenes Laertius is correct and there was a difference between Cleanthes' and Chrysippus' views, then this interpretation applies more to Cleanthes than to Chrysippus. ${ }^{26}$ It convincingly accounts for what could motivate a Stoic to tie personal identity with the soul, how a Stoic could explain the survival of all rational human souls until the end of the world cycle and, finally, why a Stoic would call human beings 'souls alone.' If Diogenes Laertius' report is accurate, however, this Stoic can only be Cleanthes.

independently existing substance according to the Stoics. She also suggests that they might have inherited this view from Plato (Ju 2009, 116, 119).

23 Long $(1982,45)$.

24 Long (1982, 52).

25 Epiphanius $a d v$. Haeres. 3.2,9 (3.37) = SVF 1.538.

26 Although I am arguing that these concerns motivated Cleanthes to tie identity to the soul, I would not, of course, deny that Chrysippus was not committed to the standard Stoic psychological account that distinguishes between an impression to do something and an assent to do it. I will argue below, however, that Chrysippus was motivated by other concerns, especially the problem presented by the Growing Argument. While tying personal identity to the soul is a way of highlighting the independence of hegemonikon and the judgements it makes, it is not necessary to separate, in the metaphysical sense, hegemonikon from the rest of the activity of psychic pneuma (cf., for example, Graver (2007, 32-34)). Chrysippus, therefore, could have been coherently committed to the standard Stoic psychological model and the claim that personal identity is an embodied soul. 


\section{Chrysippus' View: The Donkey Problem}

Chrysippus' view, that is, the view preserved in the fragments of Eusebius and Pseudo Plutarch, appears to be more complex and idiosyncratic. The fact that Chrysippus distinguished between different types of souls and claimed that the ordinary ones end up disintegrating before the end of the world cycle suggests that his account of the soul as well as identity might have differed from that of Cleanthes. Ultimately, the question is what exactly Chrysippus' view implies about personal identity. If it implies that identity persists after death, then it is more or less the same view as that of Cleanthes. If, however, it implies that identity does not properly persist after death, then it is a rather different view.

In his Against the Stoics on Common Conceptions, Plutarch records a peculiar philosophical puzzle and an even more peculiar Stoic answer that is a good starting place for determining Chrysippean understanding of personal identity. It is worth noting from the start that this fragment is not explicitly ascribed to Chrysippus. From the beginning of this treatise, however, Chrysippus seems to be treated as representing all Stoicism. ${ }^{27}$ The other Stoics are hardly mentioned at all, while Chrysippus' names shows up multiple times, including right before the passage below. It is not impossible that there is a connection between Chrysippus and this fragment, yet it cannot be established with certainty. The substance of my interpretation will rely on the fragments discussed below that are securely ascribed to Chrysippus. The fragment that contains the donkey problem, however, problematises personal identity in a revealing way and therefore it is a good starting point.

The fragment in question describes the Stoic take on the case of body switching. It is, therefore, very illuminating as it implicitly states where identity lies and under what conditions it ceases to exist. In this passage, Plutarch accuses the Stoics of hypocrisy or at least a contradiction. They claim that the attractiveness and the health of a body do not make one more likely to attain happiness, yet they also make health preferable to wisdom in the following way:

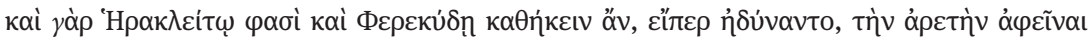

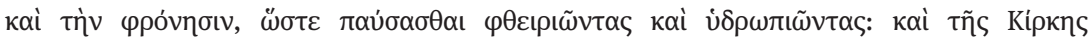

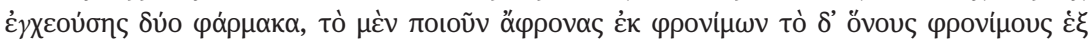

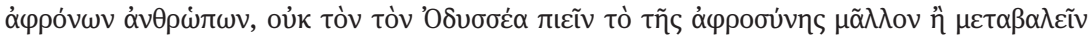

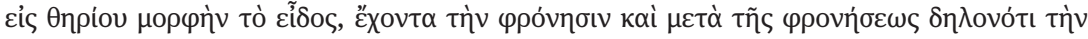

27 This is especially clear in Plut. Mor. 1059E, where the idiosyncrasy of Chrysippus' logic (it is compared to an octopus that supposedly gnaws its own tentacles) leads to the claim that the Stoics contradict common notions. Chrysippus is also treated as representing Stoicism in general earlier, in 1059B. 


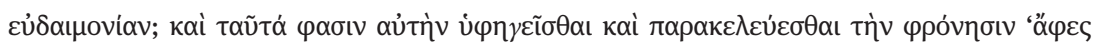

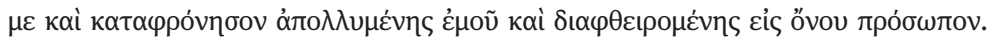

And they [the Stoics] say that it would have been fitting for Heraclitus and Pherecydes, if they could have done so, to give up their virtue and prudence in order to get rid of their pediculosis and dropsy; and that, if the potions poured by Circe were two, one making prudent men into fools and the other making foolish men into prudent donkeys, (it would be right) for Odysseus to have drunk the potion of folly rather than to have changed his form to the shape of a beast though thereby keeping his prudence - and with his prudence obviously his happiness; and this, they say, is the precept and prescription of prudence herself: 'Let me go and regard me not, for I am being undone and perverted into an donkey's head. 28

The passage describes the Stoic answer to a simple dilemma that makes one choose between two evils. Is it better to be wise in a donkey body or to be foolish but retain one's human shape? The dilemma is interesting, because it forces the chooser to prioritise either a bodily shape or a cognitive capacity. The Stoics, according to this passage, choose the latter.

This very striking answer appears to run counter to all the standard Stoic tenets, as Plutarch rightly notes. How is it possible that wisdom, the only good, is less preferable than a bodily form? The answer lies in the Stoic understanding of what it would mean to be wise in a donkey's body. In order to make sense of the Stoic choice, perhaps the puzzle could be re-phrased as follows: if one chose the second drink, would one turn into a wise person in a donkey's body or just a wise donkey? The Stoics' choice may have been informed by the assumption that this person would simply become a wise donkey. ${ }^{29}$ Once Odysseus' form is changed into that of a donkey, his wisdom becomes the wisdom of a donkey rather than a human man. The commanding faculty is the most important part of human beings, according to the Stoics; it is the aspect that makes human beings different from all other living livings. ${ }^{30}$ Numerous fragments in the Stoic corpus emphasise that humans have a privileged access to rationality which they share with the active principle, ${ }^{31}$ and animals do not possess such a faculty. ${ }^{32} \mathrm{~A}$ wise donkey, therefore, would be an oxymoron to the Stoics. Most importantly, the Stoic answer indicates that the nature of human wisdom is such that it cannot be transferred to a different body. The only way in which that wisdom would not be transferrable to a member of another species would be if personal identity was

28 Plut. Mor. 1063F-1064B, tr. Cherniss, amended.

29 Cf. Lact. Div. Inst. 3.19.

30 For example, Origen Princ. 3.1.2-3=SVF 2.988= LS 53A.

31 See Plut. Mor. 1076A = SVF 3.246 = LS 61J, where this view is attributed to Chrysippus.

32 Diog. Laert. 7.86. 
dependent on the combination of the body and the soul. Personal identity is, in that case, grounded in being an embodied rational soul. ${ }^{33}$

\section{Chrysippus' View: An Embodied Soul}

There is some additional evidence to support the interpretation that Chrysippus theorised personal identity as being an embodied soul. The Chrysippean

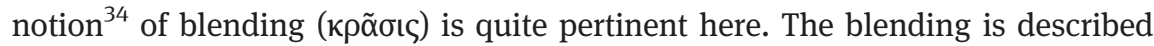
in the Stoic theory of mixtures. The theory distinguishes three types of mixtures: juxtaposition, fusion and blending. It seem that this particular type of mixture was a matter of great contention in antiquity. ${ }^{35}$ In his work On Mixture, Alexander of Aphrodisias also mostly concentrates on discussing the blending, especially how this mixture accounts for the soul's interaction with the body. Alexander of Aphrodisias's description of this mixture is as follows:

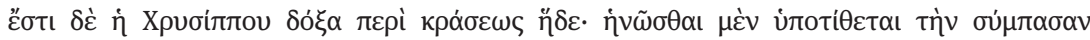

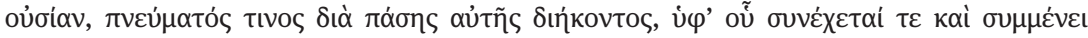

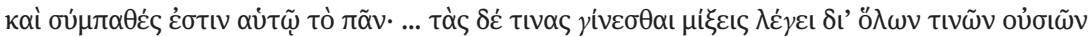

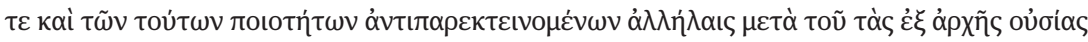

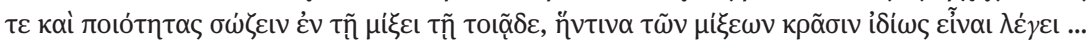

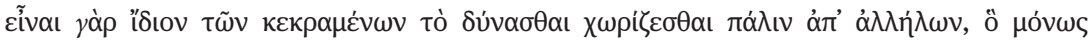

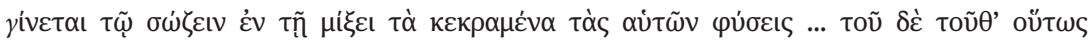

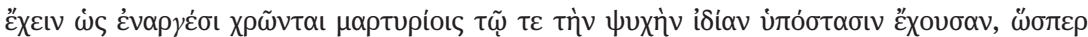

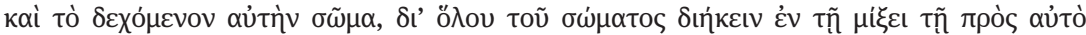

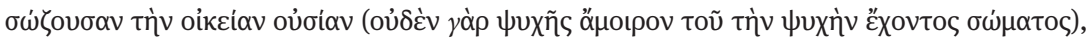

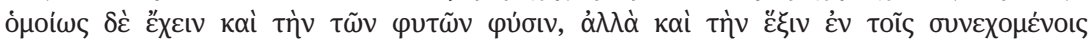
ن்

33 I adopt the term used by C. Gill in his discussion of Stoic phychophysical holism, see Gill (2006a: especially pp. 29-46 for the analysis of Stoic conceptualisation of the relationship of body and soul) and Gill (2006b, 213-217). Although Gill discusses the notion of the embodied soul in the context of psychology, it is also useful for discussing the metaphysics of personal identity as it informatively captures the condition that grounds personal identity; and, of course, the Stoic psychology and metaphysics of personhood are not unrelated topics.

34 Long and Sedley $(1987,293)$ suggest that the notion of blending most likely preceded Chrysippus, but the connection between blending and the cosmic breath was most likely Chrysippean.

35 See Plut. Mor. 1078 B-D = SVF 2.465 = LS 48E. It has also been called somewhat problematic in older scholarship but see Nolan 2006, 169-177) for an argument that Chrysippean blending is not only consistent with other Chrysippus' other physical tenets but also quite a coherent theory. 
Chrysippus has the following theory of blending: he first assumes that the whole of substance is unified by a breath which pervades it all, and by which the universe is sustained and stabilized and made interactive with itself ... Other mixtures occur, he argues, when certain substances and their qualities are mutually coextended through and through, with the original substances and their qualities being preserved in such a mixture; this kind of mixture he calls specifically 'blending' ... for the capacity to be separated again from one another is a peculiarity of blended substances, and this only occurs if they preserve their own natures in the mixture ... As clear evidence of this being so they make use of the fact that the soul, which has its own individual existence, just like the body which receives it, pervades the whole of the body while preserving its own substance in the mixture with it. For none of the soul lacks a share in the body which possesses the soul. It is just the same too with the physique of plants, and also with the tenor of things which are sustained by tenor. ${ }^{36}$

When two bodies blend, they co-extend throughout each other without losing their own specific properties and substances. The two bodies, then, are completely combined, yet they preserve their own characteristics so that when the compound is dissolved, the two bodies maintain their substances. Unlike in the case of juxtaposition, the blended bodies are not just piled together but genuinely co-extend through each other. A famous claim about blending reported by a number of sources states that, according to Chrysippus, a drop of wine blends throughout the entire sea. ${ }^{37}$ At the same time, the individual substances and properties are not destroyed, and ${ }^{38}$ the compound made by means of blending can be separated back into its constituents, just as an oiled sponge, when dipped into wine mixed with water, will separate the two liquids by absorbing water. $^{39}$

The notion of blending is important for understanding the way in which Chrysippus theorised personal identity because it shows that he might have thought of living humans, in terms of identity, as blended entities, that is embodied souls. The idea that identity depends on being an embodied soul means in order to understand what humans are, we have to think of them as souls present in bodies. Of course, the soul is the active and, more importantly, the best part of a human being, according to the Stoics. ${ }^{40}$ However, in terms of

36 Alexander of Aphrodisias Mix. 216,14-218,6 = SVF 2.473= LS 48C, tr. Long and Sedley. 37 See Diog. Laert. $7.151=$ SVF 2.479= LS 48A, Plut. Mor. 1078E = SVF 2.480 = LS 48B.

38 Lewis (1988, 86-90) argues that blending does in fact involve the destruction of the constituents while they are in the mixture. This paper does not address the question of the soul and, as a result, it is not immediately clear how such an interpretation would account for the mixture of the body and the soul.

39 Stob. 1.155,5-11 $\mathrm{W}=$ SVF 2.471 = LS 48D.

40 See Seneca Ep. $76 \cdot 9-10=S V F 3.200 \mathrm{a}=63 \mathrm{D}$. 
personal identity, or to use the Stoic term, peculiarly qualified individuals, to be a particular human being is to be a rational soul blended with a human body.

The Chrysippean fragments containing the claims that the soul is engendered after the body also suggest that personal identity is grounded in the interaction between the body and the soul. The extant evidence is not elaborate but it clearly states that, according to Chrysippus, the soul is engendered after the body because children resemble their parents in character. ${ }^{41}$ It is fairly obvious that children bear physical resemblance to their parents, which indicates that children's bodies are causally linked to their parents' bodies. Arguably, the aim of Chrysippus' argument is to show that the same applies to the properties of souls. They come into being after bodies do and, thus, they do not exist prior to conception. ${ }^{42}$ What is especially interesting for the purposes of this paper, however, is that this claim indicates that an individual is a result of the combination of the properties of the body and the soul. The particular nature of the particular soul, such as the temperament and the character of a person, depends on the body in which it resides. Personal identity, or to use a Stoic term, being a peculiarly qualified individual, is grounded in being a compound of a body and a soul.

The very same idea can be also found in Galen, although the context of this fragment is a rather different, physical, discussion. Galen reports the Chrysippean claim that on a more physical, elemental level, the soul is made out of air and fire ${ }^{43}$ but it also acquires more moisture from the bodies in which it dwells. ${ }^{44}$ The body and the soul, thus, have a mutual effect on each other. Personal identity is a result of this interaction and depends on this compound.

Consequently, the destruction of personal identity must be the separation of the body and the soul, that is, death, despite the fact that the soul still exists after this separation. A number of testimonia recording Chrysippus' definition of death survives. ${ }^{45}$ According to Nemesius, Chrysippus defined death as the

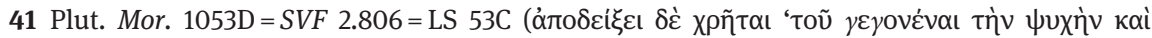

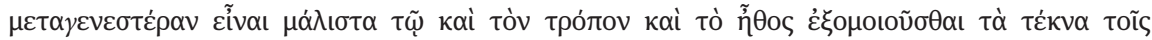

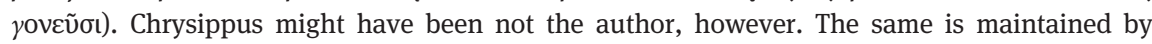
Cleanthes, according to Tertulian On the Soul, chapter $5=$ SVF 1.518 and Nemesius de Nat. Hum. 2. Cf. Cic. Tusc. 1.79, where this argument is attributed to Panaetius.

42 See, for example, Long and Sedley (1987 (vol.2):312).

43 It is worth noting that pneuma might be not a mixture of the two but, rather, constituted of each of these elements, as Sorabji argues (1988, 85-89).

44 Galen PHP 5.3.8 = SVF 2.841 = LS 47H. Cf. Cicero Tusc. 1.18, for the claim that an earthy body is warmed up by the heat of the soul.

45 See Plutarch Mor. 1052D, where Zeus is said not to die, because no separation of body and soul occurs. Cf. Salles (2009, 130-131) on this passage. 
separation of the soul and body in the argument designed to prove the corporeality of the soul as follows: 'Chrysippus says that death is the separation of soul from body. Now nothing incorporeal is separated from a body. For an incorporeal does not even make a contact with a body. But the soul both makes contact with and is separated from the body. Therefore the soul is a body. ${ }^{46}$ The 'soul' in these cases refers specifically to the commanding faculty. ${ }^{47}$

A short record of the Stoic definition of the qualified individual found in Simplicius' commentary on Aristotle's On the Soul shows that the separation of the body and the soul is also the cessation of personal identity. While introducing the issue of how souls are individuated, Simplicius inserts the Stoic contribution $^{48}$ on this topic as follows:

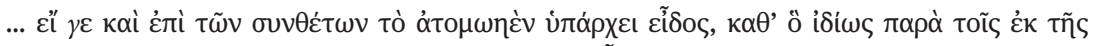

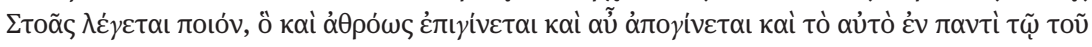

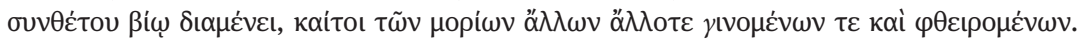

... if in the case of compound entities there exists individual form- with reference to which the Stoics speak of something peculiarly qualified, which both is gained, and lost again, all together, and remains the same throughout the compound entity's life even though its constituent parts come to be and are destroyed at different times. ${ }^{49}$

The claim about the persistence of identity in spite of material changes refers to the Chrysippean solution to the Growing Argument. The Growing Argument, also known as the Theseus Ship Paradox, is a paradox about the persistence of identity through change. Although it is typically attributed to Epicharmus, it was also adopted by the Academics to challenge the Stoics. ${ }^{50}$ The puzzle arises from the premise that material change leads to identity change, and so any material change could lead to identity change, and Socrates who goes into a barbershop at one o'clock is a different person from Socrates at two o'clock who has just had a haircut. Chrysippus' solution to this paradox consists in denying the problematic premise and showing that identity is a kind of property that does not depend on small material changes. ${ }^{51}$ This passage does, however, tell us about the scope of identity. It clearly states that peculiarly qualified

46 Nemesius 81,6-10 = SVF 2.790 = LS 45D, tr. Long and Sedley. This might have been inherited from Zeno, see Tertulian De Anima 5.

47 Sextus Empiricus $M 7.234=$ LS 53F, tr. Long and Sedley.

48 Most of the more sophisticated Stoic contributions to metaphysics were made by Chrysippus. He is responsible, for instance, for the Stoic theory of genera, see Menn (1999, 227) as well as Long and Sedley (1987, 165-166; 173).

49 Simplicius in DA 217,36-218,2 = SVF 2.395 = LS 28I, tr. Long and Sedley.

50 On the Academics' adaptation of Epicharmus' puzzle, see Sedley (1982, 256-258).

51 For analysis of Chrysippus' solution, see Sedley (1982) and Bowin (2003). Cf. Lewis (1995). 
individuals, while they persist throughout the existence of the compound, cease to exist once a compound is separated. The end of the peculiarly qualified individual, then, is not a loss or an acquisition of matter, but the separation of the compound. In the case of personal identity, this is the separation of body and soul.

Chrysippus very likely thought of identity as grounded in being an embodied rational soul. The significance difference from Cleanthes' account is that personal identity does not survive death despite the fact that the soul does survive it. ${ }^{52}$ This view is quite reasonable for a philosopher who is committed to the view that everything in this world, including human souls, is material. After all, the body does not immediately disintegrate either, yet the corpse is not a person. In the same way, the surviving soul is not a person.

\section{Chrysippus' view: 'The Smaller Substances'}

One of the most puzzling claims in the extant evidence on Chrysippean views on the post-mortal survival of the souls is the claim that the souls survive having

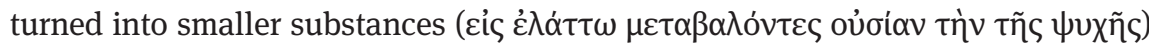
after death. An even more bewildering aspect of the post-mortal survival of the ordinary souls is the temporal aspect of the whole process. In this section, therefore, I am going to explore Chrysippus' account of the soul and determine why the souls survive 'for a little while' and what determines how long they do survive. In accordance with the conclusions reached above, the issue at stake here is not a person Socrates - the personal identity ceases at the point of death - but the remaining soul of Socrates. The question of what happens to the soul of Socrates after death is thus comparable to the question of what happens to the body of Socrates after death, in the sense that the discussion no longer concerns Socrates per se.

In order to answer this question, it is necessary to start with the question of what the smaller substances are, or what is left of the soul once it departs from the body. ${ }^{53}$ Arguably, a fairly natural way of interpreting the term 'a smaller substance' would be to read it as referring to the elemental theory. A human being is a compound in several ways. On the one hand, a person is a compound of the body and the soul, and death marks the dissipation of this compound. On

52 This is contra Lewis (1995, 97-99).

53 Cf. Scholia in Hom. Illiad $65=$ SVF 2.815 for the claim that, according to Chrysippus, the soul becomes round after the separation. 
the other hand, a person is also a compound of the four elements, like all other living creatures. ${ }^{54}$ The composition and dissipation of the compounds made of elements is extensively described in Stoic elemental theory.

The evidence for Chrysippus' elemental theory is fairly abundant. ${ }^{55}$ Possibly the most elaborate account is preserved in Stobaeus. It states not only that, according to Chrysippus, terrestrial beings ultimately resolve into the four elements, but also that the very term 'element' can have three meanings. First, it can refer to fire, because it is the element sui generis; second, it can refer to the four elements; and, finally, it can refer to anything that causes generations from itself into some end which subsequently resolves back into the original form. ${ }^{56}$ The very concept of an element involves both creation from and resolution into the original elemental state. Following the dissolution of the compound of the body and the soul, the dissolution of the elemental compound ought to take place.

A living person is made out of fire, air, water and earth, and while the way in which the elements interact when they make up a person is complex, ${ }^{57}$ several fragments suggest that both the body and the soul have dominant elements. The soul is commonly described as consisting of fire and air, while the body is described as 'damp' and so, implicitly, consisting of earth and water. ${ }^{58}$ If a human being consists of four elements, then the elemental disentanglement at death would quite naturally mean that the surviving soul is a smaller substance as it contains two rather than four elements. In the passage of Galen cited above, the soul is said to gain dampness from the body, but presumably this kind of property would be lost once the soul is not in contact with the body.

The most puzzling aspect of the survival of the souls is the temporality of this phenomenon. What could possibly motivate Chrysippus' claim that the ordinary souls survive for some time only? I would argue that elemental theory might have played a role here. The elemental changes take place due to two kinds of processes: condensation and rarefication. These two processes are foundational for explaining the world cycle. ${ }^{59}$ Condensation and rarefication also play a role in the formation of the soul and, therefore, they are often

54 Chrysippus' elemental theory is outlined in Stob. 1.129,2-130,13 W=SVF 2.413=LS 47A.

55 It is not unproblematic, however. See White (2003, 133-136).

56 Stob. 1.129,2-130,13 W=SVF 2.413=LS 47A. Cf. Diog. Laert. 7.136-7.

57 Most of material things have all four elements in their constitution, see Cooper $(2009,115)$.

58 Galen PHP 5.3.8=SVF 2.841=LS 47H; Alexander of Aphrodisias Mix. 224,14-17,23-6=SVF

$2.442=$ LS 47I.

59 Diog. Laert. 7.142; Galen Nat. fac. 106,13-17 = SVF 2.406= LS 47E. 
mentioned in connection to Stoic embryology. Although there is no extant evidence that explicitly addresses the question of how the soul dissipates, the Chrysippean account of the embryo formation provides less direct, but still relevant, information. The account of embryo formation involves not only a fairly detailed account of the physiological process leading to the formation of the rational soul but also describes the identity-forming change, that is, the conditions that are necessary for pneuma to attain the state of the soul. From this, it is possible to infer the conditions under which the pneuma is no longer in a state to be a human soul. The Chrysippean embryological account, thus, might shed light on his account of the post-mortal survival of the soul. ${ }^{60}$

Plutarch's critique ${ }^{61}$ of Chrysippus' views ${ }^{62}$ is one of the main sources for Stoic embryology. In an attempt to show that Chrysippus' views on the effects of cooling and heating on the soul are contradictory, Plutarch cites his account of embryo-formation. According to Chrysippus, an embryo is like a plant while it is in the womb but when it is born, it is cooled and hardened by the air and, as a result, turns into an animal. ${ }^{63}$ It is noteworthy that the soul is only properly formed at the time of birth, when an embryo is cooled and hardened by the air. As T. Tieleman argues, ${ }^{64}$ this account of the birth of the soul is rather well constructed: 'that the soul should come into being as soon as the physiological

60 See Tieleman (1991, 123).

61 Plutarch claims that Chrysippus' view is contradictory because it suggests that the soul fully develops (and, implicitly, becomes fine) by condensing at birth, yet it is seems impossible that condensation makes something finer rather than thicker. Plutarch, however, appears to misrepresent the Stoic view here. Nothing in Chrysippus' quotes suggests that the exposure to the air rarefies the soul. In fact, in Hierocles' fragment on Stoic embryology, pneuma is said to become finer gradually during gestation (Hierocles 1.5-33= LS 53B, see n. 68), so birth does not make the pneuma finer, because it has already been made such during the gestation. The condensation serves a different purpose. Stoic sources and medical tradition describe physical pneuma in embryo as hot (Diog. Laert. 7.157; cf. Graver $(2007,21)$ on the use of this in pre-Stoic medical tradition, see Tieleman (1991, n.36). Embryo's exposure to cold air, then, tempers the heat of pneuma, so that a newborn can process air (a naturally cold element) and support itself by breathing (cf. n.64).

62 Zeno had a rather different account. According to the reports of Eusebius and Galen (Praep. Evang. 15.20,1 and Hist. Phil. $108=$ SVF 1.128), he maintained that embryo does have a soul that is a small part of the parental soul.

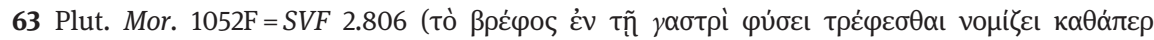

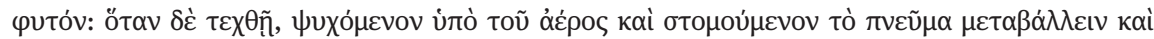

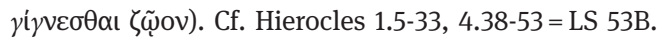

64 This comment is in reference to a fragment from Ps. Plutarch. While Ps. Plutarch was most likely referring to a work of Diogenes of Babylon's, Tieleman also argues that this account can also be attributed to Chrysippus and Cleanthes (1991, 124). 
mechanism by which it sustains and nourishes itself begins, is a neat and economical theoretical construct. ${ }^{65}$

While the crucial part for the formation of the soul is birth and the exposure to the air, ${ }^{66}$ an embryo undergoes important gradual change during gestation. This piece of information is found in another fragment that is somewhat more detailed than Plutarch, yet records the very same account. In this fragment, the Stoics are said to consider an embryo to be not an animal but a part of mother's womb. Just like a fruit is a part of a tree until it ripens, falls and becomes a distinct entity in its own right, an embryo is a part of its maternal womb until it is born and becomes an animal. ${ }^{67}$ The comparison with a piece of fruit shows that the development of an embryo is a gradual process during which it undergoes a slow but radical change. A similar claim is found in Hierocles. He maintains that while the decisive moment for the formation of the soul - that is, birth - is quite sudden, the actual process of an embryo's growth is gradual, as follows: 'In the early stages, the physique is breath of a rather dense kind and considerably distant from soul; but later, when it is close to birth, it becomes finer ... ${ }^{\text {,68 }}$

The disintegration of the soul, I would argue, is this process in reverse. While during gestation the soul undergoes rarefication, ${ }^{69}$ post mortem it starts condensing and, as the passage from Ps. Plutarch suggests, eventually turns

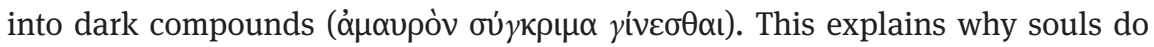
not cease to be immediately. ${ }^{70}$ Souls last for a while because disintegrating, just

65 Tieleman (1991, 122).

66 This part might seem like a counter-case for the interpretation proposed in this paper so far, as the proper coming-into-being of the soul coincides with the coming-into-being of a person in a proper sense. There is, however, no inconsistency between theorising human identity as an embodied soul and making soul-formation and identity-formation simultaneous. Being an embodied soul requires both a body and a soul, and it cannot come into existence until both of its components are properly in existence. It is only when the soul, due to the cooling of the matter, comes into being that the compound of the body and the soul is formed.

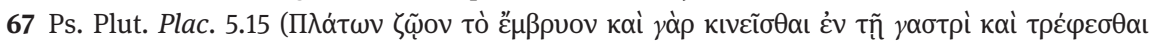

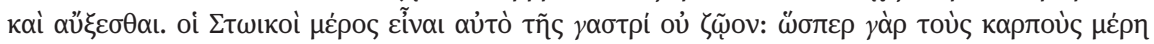

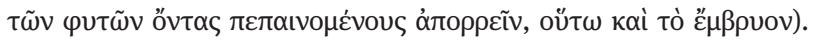

68 Hierocles 1.5-33 = LS 53B, tr. Long and Sedley.

69 Birth itself might be a condensing event, possibly the type of event that stops the rarefication of the soul at the necessary point for it not to become too fine.

70 Cf. Ju (2009, 115-120). In regards to Chrysippus' view that the wise souls last until the conflagration while the ordinary ones do not, Ju argues that there are two different types of dissipation that souls can be subjected to: mere resolution and the conflagration. Only the wise souls undergo conflagration, while the ordinary people undergo mere resolution, which is a process by means of which a compound dissolves into components. 
like forming, takes a certain amount of time. Another parallel here could be a body. It takes a while for a body to disintegrate post mortem, and the soul, being a corporeal entity as well, would also take some time to cease to exist.

It is noteworthy that this reading of how humans come into being and cease to exist is consistent with the definition of the peculiarly qualified individual preserved by Simplicius. Peculiarly qualified individuals come into existence and cease to exist immediately. The point of birth, when the soul solidifies, and the moment of death, when the compound separates, would be such moments in this case. Identity, furthermore, persists throughout the life of a compound despite the increase or the decrease of the matter in the compound. Once the compound is separated, however, personal identity ceases to exist and the remaining components of the previous compound, that is, the body and the soul, disintegrate over a long period of time. The claim that humans survive as smaller substances for some time, then, is quite consistent with other views attributable to Chrysippus, and overall, it fits coherently into Chrysippean metaphysics.

\section{Chrysippus' view: The Wise Souls}

Given everything that has been argued, Chrysippus' claim that the souls of the wise men survive until conflagration appears to present a strange exception. What could possibly motivate Chrysippus to claim that these souls last until the end of the world cycle?

The claim that the souls survive death appears to show a Platonic influence. Chris Gill shows, however, that it also follows rather naturally from Stoic commitments, as follows: 'What it represents is a logical consequence of the thought that pneuma has a physical existence and that there are varying degrees of pneumatic tension, which are more or less cohesive and enduring. Hence, the wise, whose stable and virtuous character (diathesis) constitutes the highest possible state of pneumatic tension, will survive longest beyond the dissolution of the rest of the body. ${ }^{71}$ Thus, the longevity of the wise souls can be explained by using Stoics' own physical framework. The claim was most likely motivated by the pneumatic theory and the idea that this longevity is a by-product of highlevel tension found in those souls that possess virtue. ${ }^{72}$

71 Gill (2006a, 81). Cf. Bénatouil (2005).

72 This is a fairly common suggestion in the scholarship on this topic, see, for example, Algra's $(2009,371)$ analysis for a very similar conclusion. 
In fact, strength plays a rather important role in the Stoic conceptualisation of virtue, a distinguishing property of the wise man, even if this notion is not of Stoic origin. The idea that virtue is a kind of strength is, as Malcolm Schofield shows, Socratic, and especially prominent in Xenophon's depictions of Socrates. ${ }^{73}$ It is adopted by Cleanthes, who says virtue as a tension is a 'stroke of fire' ( $\pi \lambda \eta \gamma \eta \dot{\eta}$ זupòs) and suggests that when the soul acquires the level of tension needed for understanding what behaviour one ought to pursue, this tension is called

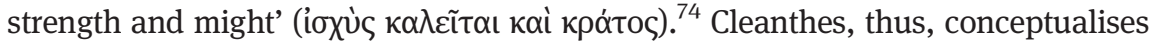
virtue not only as wisdom but also as a kind of strength. ${ }^{75}$ Although Chrysippus makes strength the secondary virtue, ${ }^{76}$ it is noteworthy that the later tradition appears to merge Cleanthes' and Chrysippus' theories and 'it may be that Chrysippus himself has already downgraded the status of tension as virtue. ${ }^{77}$

This reading can be further supported by rather extensive evidence on Stoic views regarding the corrosive effect of pleasure on the soul. The love of pleasure is explicitly said to be a parallel to a bodily disease in a fragment found in Diogenes Laertius. ${ }^{78}$ Galen, citing from Chrysippus' On Emotions, records the view that there is a parallel between good tension in the body and the soul and that both of them constitute health in their respective areas. ${ }^{79}$ The same idea is also found in Cicero's Tusculan Disputations. ${ }^{80}$ The wise souls, then, last for a very long time, because they contain very high levels of pneumatic tension, and they are 'healthy', that is, not corroded by wrong beliefs and pursuits of pleasure.

In terms of personal identity, the wise man is no different from an ordinary person in the sense that both personal identities would cease at the time of death. Thus Socrates' soul survives, but Socrates does not. The wise men are special only in terms of the longevity of their souls. Whereas the ordinary souls start condensing after separation from the bodies, the wise souls do not undergo such a change until the conflagration due to their high pneumatic tension.

73 Schofield (2013, 18-19).

74 Plut. Mor. 1034 D-E.

75 Schofield (2013, 20).

$76 \mathrm{He}$ had good reason to do so, because, as Schofield shows, Cleanthes' promotion of enkrateia among the virtues diminished the importance of rational thinking when making hard ethical decisions, see Schofield (2013, 26).

77 Schofield (2013, 28). Cf. Bénatouil (2005, 12).

78 Diog. Laert. 7.115.

79 Galen PHP 5.2.22-24, 26-27 = SVF 3.471, 471a. For the physiological effects of emotions on the soul, see Rapp (2006, 196-197).

80 Cic. Tusc. 4.30-1. Cf. Graver $(2002,205)$ for an argument that these parallels are typically Chrysippean. 
Presumably, the motion and heat of high pneumatic tension keep these souls from cooling, hardening and condensing.

\section{Demons}

The Stoics were in unanimous agreement that souls do persist through death but the details of their accounts, as I have argued in this paper, can be quite different. There is a small set of evidence that explains the survival of the souls with a reference to demonology, a rarely-discussed area of Stoic thought. The main piece of evidence here is a passage from Sextus Empiricus cited below, and this fragment is often discussed together with the other fragments on the post mortal survival of the soul, although, typically, little emphasis is put on the claim that the souls survive as demons. In this section, I will argue that the connection between the demonology fragments and the other evidence regarding the Stoics accounts of the post-mortal survival of the soul is tenuous. The evidence on the Stoic demonology, therefore, is worth noting as a part of the Stoic philosophical framework, although it does not change the interpretation of the Cleanthean and Chrysippean accounts of the post-mortal survival of the soul and personal identity presented above.

The central piece of evidence on the survival of the souls as demons is a fragment found in Sextus Empiricus' discussion of the arguments regarding the divine existence. Sextus presents the Stoic critique of the Epicurean account of what happens to the soul after death and, in the process of explaining Stoic counter-arguments, records the claim that souls persist after death in the following manner:

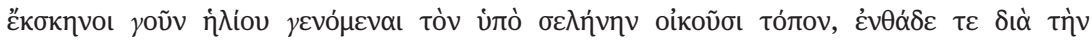

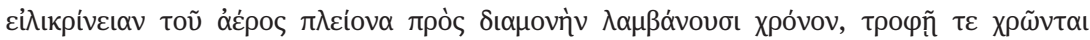

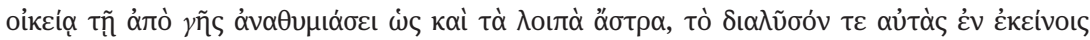

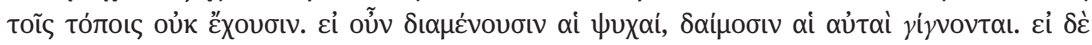

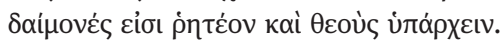

At any rate, after becoming disembodied they reside in the region below the moon, and there, because of the purity of the air, they get to keep going for a longer time, and they find a congenial food in the exhalation that rises from the earth (as the rest of the stars do as well), and in those regions they do not have anything that will dissolve them. So, if souls keep going, they are the same as spirits [daimones]; and if there are spirits, it must be said that gods too are real ... ${ }^{81}$

81 Sextus Empiricus $M$ 9.73-4=SVF 2.812, tr. Bett. 
This account of the post-mortal survival of the souls is rather different from the accounts preserved by Eusebius, Ps. Plutarch and Diogenes Laertius. The first question to ask, then, is how compatible the view recorded here is with the views preserved in other places and whose view this is likely to be. The text unfortunately does not mention either the conflagration or the distinction between the ordinary and the wise souls, and, therefore, it is not clear whether the scenario described here applies to all or just the wise souls.

The lack of distinction could be an indication that this is Cleanthes' view. The context in which this account is found, however, points towards Chrysippus because it was Chrysippus and Posidonius who engaged in the arguments with the Epicureans the most. ${ }^{82}$ Attributing the view to the third head of the Stoa is also not unproblematic, however. Chrysippus' account contains a significant distinction between the ordinary and the wise souls. If the souls dwelling in the region below the moon are wise, ${ }^{83}$ then the explanation for their longevity lies in their environment rather than internal properties, which would be out of sync with Chrysippean ethics. These two explanations do not necessarily contradict each other (and it is possible to maintain that strong souls are further supported by their environment), yet it would be strange to build up an elaborate theory about the physical strength and the health of the wise soul only to claim that it survives due to environmental factors. If the souls that dwell below the moon and become demons are ordinary, then the fact that they are supposed to dissipate after some time presents a problem. ${ }^{84}$

There is another possible source for the account preserved by Sextus Empiricus. As mentioned above, it is not only Chrysippus but also Posidonius who engaged in the debates with the Epicureans. Diogenes Laertius records a citation from Posidonius' Physics about the nutriment of the heavenly bodies that presents a very similar cosmological picture to the one found in Sextus' passage, ${ }^{85}$ although this cosmology is not exclusively Posidonian. ${ }^{86}$ Posidonius did, however, write a treatise on demonology entitled On Heroes and Demons, ${ }^{87}$

82 For Chrysippus, see Plut. Mor. 1054B=SVF 2.539; Eusebius Praep. Evang. 261A = SVF 2.978. For Posidonius, see Cic. Nat. D. 1.123 = fr. 22a EK. Cf. Algra (2009, n.34).

83 See Diog. Laert. 7.151 for the claim attributed to the Stoics in general that the surviving souls of the souls of the good are heroes. Cf. Algra's $(2009,373)$ discussion of this passage.

84 Cf. Algra (2009, 386).

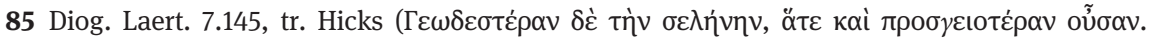

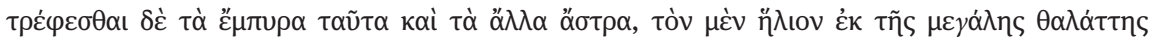

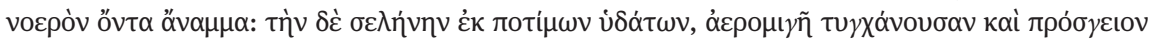

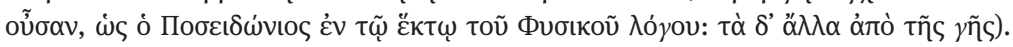

86 See Stob. 1.219,24 W = SVF 2.677 for a similar view attributed to Chrysippus.

87 Posidonius fr. 24 EK. 
and view of the soul is in sync with account preserved by Sextus. ${ }^{88}$ Attributing this view to Posidonius does not, of course, rule out the possibility that Chrysippus also held this view. As far as the extant fragments are concerned, it is easier to attribute this view to Posidonius rather than to Chrysippus. Chrysippus certainly wrote about demons ${ }^{89}$ but whether the kind of theory that is found in Sextus Empiricus would also be advocated by Chrysippus and included in his account of the post-mortal survival of the souls is inconclusive. As a result, it is not clear whether demonology plays a significant explanatory role in the early Stoic accounts of the post-mortal survival of the soul.

\section{Agree to Disagree: Concluding Remarks}

I have argued that if Diogenes Laertius' record of the disagreement between Cleanthes and Chrysippus is taken to be a reliable piece of information - and there are several reasons to do so - then it follows that there was a subtle yet important difference between these two early Stoics regarding their views about not only the soul but also personal identity. Cleanthes subscribed to the view that personal identity is grounded in the soul alone. Chrysippus, meanwhile, had a more complex view. According to him, personal identity is grounded in being an embodied rational soul. After death, the tenors of ordinary souls dissipate after a while, just like the tenors of all human bodies dissipate, while the souls of the wise, being stronger and healthier, last until the end of the world cycle. It is noteworthy, however, that the fact that Chrysippus and Cleanthes held different views does not necessarily mean that Chrysippus' account ought to be construed as explicitly criticising the view of his teacher.

Possibly the pertinent background here is, again, the Growing Argument. Chrysippus' solution to this paradox primarily consists in denying that identity is grounded in matter, and this move has some important consequences for the scope of personal identity. It commits Chrysippus to the view that identity does not depend on material parts and it does not 'go' where material parts 'go.' Chrysippus' account shows that Socrates walking out of a barber shop is the same person who walked into the barber shop an hour ago, despite the fact that a part of Socrates, his hair, is left behind. Consequently, assigning post-mortal

\footnotetext{
$88 \mathrm{Ju}(2009,113-114)$ uses Sextus' passage for her discussion of Posidonius' conception of the soul.

89 Suda $=$ SVF 2.1205 and Cic. Div. 2.70, 144. There is also some evidence in Plut. Mor. $1051 \mathrm{C}=$ SVF 2.1178, but see Algra (2009, 379-384).
} 
identity to a part of the body-soul compound would be not quite coherent. It is more natural for Chrysippus to maintain that identity ceases to exist at the time of the separation of the compound, and it does not persist even though the parts of the compound keep on persisting. If this is the case, then it is not quite accurate to interpret Chrysippus' view as a critique of Cleanthes' views. The target of Chrysippus' critique is the Academics ${ }^{90}$ and the implications of the Growing Argument. The fact that his account ended up contradicting Cleanthes' view might have been, after all, only a by-product of his critique of the Stoics' opponents and, therefore, somewhat accidental.

\section{References}

Algra, K. 2009. "Stoics on Souls and Demons: Reconstructing Stoic Demonology." In Body and

Soul in Ancient Philosophy, edited by D. Frede and B. Reis, 359-388. Berlin: Gruyter.

Arnim, H. F. A. V. 1903-1924. Stoicorum Veterum Fragmenta, Vol. 3. Leipzig: Teubner.

Bénatouïl, T. 2005. "Force, fermeté, froid: la dimension physique de la vertu stoïcienne." Philosophie Antique 5:5-30.

Bett, R. 2012. Sextus Empiricus: Against the Physicists. Cambridge: CUP.

Bobzien, S. 1998. Determinism and Freedom in Stoic Philosophy. Oxford: OUP.

Bowin, J. 2003. “Chrysippus' Puzzle about Identity." Oxford Studies in Ancient Philosophy 24:239-251.

Cherniss, H. 1976. "Plutarch.” In Moralia, Volume XIII. Part 2: Stoic Essays, eds. T. Page,

T. Capps, W. Rouse, L. Post, and E. Warmington. Cambridge, MA: Harvard University Press.

Chiesara, M. L. 2001. Aristocles of Messene: Testimonia and Fragments. Oxford: OUP.

Cooper, J. M. 2009. "Chrysippus on Physical Elements." In God and Cosmos in Stoicism, edited by R. Salles, 93-117. Oxford: OUP.

Edelstein, L., and I. G. Kidd, ed. 1989. Posidonius, vol. 1: The Fragments, 2nd ed. Cambridge: CUP.

Gill, C. 2006a. The Structured Self in Hellenistic and Roman Thought. Oxford: OUP.

Gill, C. 2006b. "Psychophysical Holism in Stoicism and Epicureanism." In Common to Body and Soul: Philosophical Approaches to Explaining Living Behaviour in Greco-Roman Antiquity, edited by R. A. H. King, 209-231. Berlin: Gruyter.

Gourinat, J.-B. 2007. “Akrasia and Enkrateia in Ancient Stoicism: Minor Vice and Minor Virtue?” In Akrasia in Greek Philosophy: From Socrates to Plotinus, edited by C. Bobonich and P. Destrée, 215-248. Leiden: Brill.

Gourinat, J.-B. 2009. "Stoics on Matter and Prime Matter." In God and Cosmos in Stoicism, edited by R. Salles, 46-69. Oxford: OUP.

Graver, M. 2002. Cicero on The Emotions: Tusculan Disputations 3 and 4. Chicago: Chicago University Press.

Graver, M. 2007. Stoicism and Emotion. Chicago: University of Chicago Press.

90 See Bowin (2003, 240-246) for an argument that Chrysippus solution is a reduction ad absurdum of the Academics' paradox. 
Hicks, R. 1924. Diogenes Laertius: Lives of Eminent Philosophers. Cambridge, MA: Harvard University Press.

Hoven, R. 1971. Stoïcisme et Stoïciens face au problème de l'au-delà. Paris: Les Belles Lettres. Inwood, B. 2014. "Walking and Talking: Reflections on Divisions of the Soul in Stoicism." In Partitioning the Soul: Debates from Plato to Leibniz, Topoi: Berlin Studies of the Ancient World, Vol. 22, edited by K. Corcilius and D. Perler, 63-84. Berlin: De Gruyter.

Ju, A. E. 2009. "Stoic and Posidonian Thought on the Immortality of Soul." The Classical Quarterly 59 (1):112-124.

Lewis, E. 1988. "The Stoic Theory of Mixture." Bulletin of the Institute of Classical Studies 35 (1):84-90.

Lewis, E. 1995. "The Stoics on Identity and Individuation." Phronesis 40 (1):89-108.

Long, A., and D. Sedley, ed. 1987. The Hellenistic Philosophers, Vol. 2 . Cambridge: CUP.

Long, A. A. 1982. "Soul and Body in Stoicism." Phronesis 27 (1):34-57.

Mansfeld, J. 2016. "Theodoret of Cyrrhus's Therapy of Greek Diseases as a source of the Aëtian Placita." Studia Philonica Annual 28:151-168.

Menn, S. 1999. "The Stoic Theory of Categories." Oxford Studies in Ancient Philosophy $17: 215-247$.

Nolan, D. 2006. “Stoic Gunk.” Phronesis 51 (2):162-183.

Rapp, C. 2006. "Interaction of Body and Soul: What the Hellnistic Philosophers Saw and Aristotle Avoided." In Common to Body and Soul: Philosophical Approaches to Explaining Living Behaviour in Greco-Roman Antiquity, edited by R. A. H. King, 187-208. Berlin: Gruyter.

Rist, J. M. 1977. "Zeno and Stoic Consistency." Phronesis 22 (2):161-174.

Salles, R. 2009. "Chrysippus on Conflagration and the Indestructability of the Cosmos." In God and Cosmos in Stoicism, edited by R. Salles, 118-134. Oxford: OUP.

Schofield, M. 2013. "Cardinal Virtues: A Contested Socratic Inheritance." In Plato and the Stoics, edited by A. Long, 11-28. Cambridge: CUP.

Sedley, D. 1982. "The Stoic Criterion of Identity." Phronesis 27 (3):255-275.

Sedley, D. 2003. "The school, from Zeno to Arius Didymus." In The Cambridge Companion to the Stoics, edited by B. Inwood, 7-32. Cambridge: CUP.

Sorabji, R. 1988. Matter, Space and Motion: Theories in Antiquity and Their Sequel. London: Duckworth.

Tieleman, T. 1991. "Diogenes of Babylon and Stoic Embryology. Ps. Plutarch, "Plac.” V. 15.4 Reconsidered." Mnemosyne 44 (Fasc. 1/2):106-125.

Vogt, K. M. 2009. "Sons of the Earth: Are the Stoics Metaphysical Brutes?" Phronesis 54 (2):136-154.

Wachsmuth, C., and O. Hense. 1884-1912. Ioannis Stobaei Anthologium, Vol. 5. Berolini: Apud Weidmannos.

White, M. J. 2003. "Stoic Natural Philosophy (Physics and Cosmology)." In The Cambridge Companion to the Stoics, edited by B. Inwood, 124-152. Cambridge: CUP. 